\title{
DEPRESSIVE SYMPTOMS IN MEDICAL STUDENTS
}

Marinela Knezevic ${ }^{1}$, Danijela Djoković ${ }^{2}$, Dragana Ignjatovic-Ristic ${ }^{2}$, Jelena Djoković ${ }^{3}$, Jelena Jovic ${ }^{4}$

${ }^{1}$ Serbian Armed Forces, military post 4219 Sabac

${ }^{2}$ Psychiatry Clinic, Clinical Center Kragujevac, Zmaj Jovina 30, Kragujevac, Serbia.

${ }^{3}$ Faculty of Medicine, University of Kragujevac

${ }^{4}$ Faculty of Medicine, University of Kosovska Mitrovica, Serbia

\section{SIMPTOMI DEPRESIJE KOD STUDENATA MEDICINE \\ Marinela Knežević1, Danijela Đoković ${ }^{2}$, Dragana Ignjatović-Ristić2, Jelena Đoković ${ }^{3}$, Jelena Jović ${ }^{4}$ 'Srpske oružane snage, vojna pošta 4219 Šabac \\ ${ }^{2}$ Klinika za psihijatriju, KC Kragujevac, Zmaj Jovina 30, Kragujevac, Srbija \\ ${ }^{3}$ Fakultet medicinskih nauka, Univerzitet u Kragujevcu, Srbija \\ ${ }^{4}$ Medicinski fakultet, Univerzitet u Kosovskoj Mitrovici, Srbija}

\begin{abstract}
Mental disorders represent a growing problem in the student population. There has been a recent increase in the prevalence of depressive symptoms among medical students. The objective of this study was to determine the frequency of depressive symptoms in medical students to provide insight into this problem in our country. In total, 131 fourth-year medical students were included in the study. To determine rates of depressive symptoms in the student population, we used the BDI IA. Symptoms of depression were found in $26.7 \%$ of students. The most common levels of depression were mild and moder-

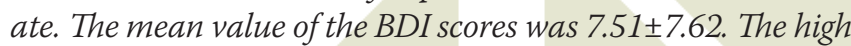
level of depressive symptoms found in medical students highlights the need for more comprehensive insight and follow up of this problem in the student population.
\end{abstract}

Key words: medical students, depressive symptoms, mental health

\section{SAŽETAK}

Mentalne bolesti $i$ poremećaji predstavljaju sve veći $z$ dravstveni problem u studentskoj populaciji. Cilj ove studije je bio da utvrdimo učestalost depresivnosti kod studenata medicine u našoj zemlji $i$ time damo bolji uvid u ovu problematiku kod nas. U studiji je učestvovao 131 student četvrte godine medicine. Za utvrđivanje depresivne simptomatologije kod studenata korišćena je Bekova skala za samoprocenu depresivnosti. Simptomi depresivnosti nadeni su kod $26.7 \%$ studenata. Najčešće se radilo o depresivnosti blagog $i$ umerenog intenziteta. Srednja vrednost na BDI

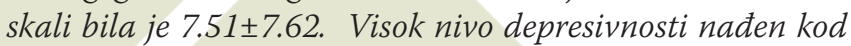
studenata medicine upućuje na potrebu za sveobuhvatnijim sagledavanjem i praćenjem ove problematike u studentskoj populaciji.

Ključne reči: studenti medicine, depresija, mentalno zdravlje

\section{INTRODUCTION}

Previous studies have shown that mental disorders represent a growing problem in the student population (1-3). Medical education is often considered to be very stressful due to its duration and the nature of the topic studied (4). The frequency of depression in medical students is greater compared to that in the general population and varies from $10-25 \%$ according to various studies (5-10).

The epresence of depression in medical students is associated with a greater risk of suicide $(11,12)$, increased use of benzodiazepines (13) and a poorer quality of life (14). The incidence Depression among students is accompanied by a decrease in academic performance, i.e., a lower average grades (15). Depressed medical students, especially those with a higher depression score, find that their opinion is less respected than the opinions of others and that they are viewed as less capable when compared to other students (12). Unrecognised and untreated depression during medical studies seems to have subsequent consequences, as indicated by a higher rate of depression and suicide among doctors compared to other professionals (16).

Despite the increased frequency and obvious consequences of various psychological problems, medical students are generally unwilling to seek adequate professional help. They would much rather seek self-treatment or ask for help from family members and friends $(17,18)$. The reason for this behavior is that mental illness is regarded as a form of weakness and is associated with a potential negative influence on future career development (19). As a consequence, often neither mental healthcare providers nor members of the public have proper insight into the fre- 
quency of mental problems in students. In this study, we aimed to establish the frequency of depression in medical students in our country.

\section{PATIENTS AND METHODS}

\section{Patients}

This research was conducted as an observational cross-sectional study from May to June 2010. A total of 131 fourth-year students, representing more than half of all students (response rate $=54 \%$ ) at the Medical Faculty in Kragujevac participated in the study. Students participated in the research voluntarily and anonymously.

\section{Methods}

To measure depression, we used Beck's Depression Inventory (BDI), a 21-item self-report questionnaire. The BDI is a well-known scale used for the self-assessment of depression in clinical and non-clinical populations (20). Currently, the BDI-II is most widely employed, but we used the BDI-IA. We did thisused this version because the results presented in this paper are a part of larger study that, began at a time during whichwhen the BDI-II version was not widely used and because this version is free. The BDI-II version was validated in 2011 on a Serbian student sample. A study showed that the psychometric characteristics of this version were in agreement with the literature (internal consistency was 0.87 ) (21). The cut-off points for the BDI were as follows: 0-9, no depression; 10-15, mild depression; 16-19, mild to moderate depression; 20-29, moderate to severe depression; and 30-63, severe depression (22). The various symptoms of depression can be grouped into a limited number of clusters. The structure of BDI consists of several factors $(23,24,25)$. Some of these factors were established in the BDI-I. The first factor, the affective cluster (the sum of scores on items 1, 4, 10, 11, and 12 from the BDI), represents the core elements of depression and are represented by the following symptoms: 1 , sadness; 4 , dissatisfaction; 10, crying episodes; 11 , irritability; and 12, social withdrawal. The second factor, the cognitive cluster (items 2, 3, 5, 6, 7, 8, 9, 13, 14, and 20), addresses the following cognitive symptoms: 2 , pessimism; 3 , sense of failure; 5 , guilt; 6 , expectation of punishment; 7 , self-dislike; 8 , self-accusation; 9, suicidal ideation; 13, indecisiveness; 14, change in body image; and 20, somatic preoccupation. The third factor, the somatic cluster (items 15, 16, 17, 18, 19, and 21), assesses the presence of the following symptoms: 15 , slowness ; 16 , insomnia; 17 , fatigue; 18 , change in appetite; 19 , loss of weight; and 21, loss of sexual interest (25).

\section{Statistical methods}

The data are expressed as the mean \pm standard deviation and percentage (\%). To establish the difference in the frequency of depression with respect to gender, the Chisquared test was used. The Mann-Whitney test was used to determine differences in levels of depression between male and female students (the scores for the various items are not normally distributed in these groups ). Analyses were performed with the Statistical Package for the Social Sciences (SPSS), version 13.0. P-values $\leq 0.05$ were considered statistically significant.

\section{RESULTS}

In the examined student sample, $47.3 \%$ (62) of participants were male.

Symptoms of some type of depression were found in $26.7 \%$ (35) of the students (Table 1). Of the males, $25.8 \%$ (16) were depressed, and of the females, $27.5 \%$ (19) were depressed. The mean BDI score was 7.51 \pm 7.62 (Table 2). There was no statistically significant difference in the frequency $(\mathrm{p}=0.823)$ and level $(\mathrm{p}=0.921)$ of depression among male and female students.

\begin{tabular}{|l|l|}
\hline Depression level (BDI) & $\%\left(\mathbf{N}^{*}\right)$ \\
\hline No depression (0-9) & $73.3 \%(96)$ \\
\hline Mild depression (10-15) & $14.5 \%(19)$ \\
\hline Mild to moderate depression (16-19) & $3 \%(4)$ \\
\hline Moderate to severe depression (20-29) & $7.6 \%(10)$ \\
\hline Severe depression (30-63) & $1.5 \%(2)$ \\
\hline
\end{tabular}

Table 1: Number of examinees by category on the BDI scale ("number of examinees)

\begin{tabular}{|l|l|}
\hline & BDI \\
\hline Men & $8.16 \pm 9.17$ \\
\hline Women & $6.93 \pm 5.90$ \\
\hline Total & $7.51 \pm 7.62$ \\
\hline
\end{tabular}

Table 2: Mean scores on the BDI scale

\begin{tabular}{|l|l|}
\hline Cluster & Score \\
\hline Affective & $2.56 \pm 2.67$ \\
\hline Cognitive & $2.66 \pm 3.46$ \\
\hline Somatic & $2.28 \pm 2.86$ \\
\hline BDI total & $7.51 \pm 7.62$ \\
\hline
\end{tabular}

Table 3: Cluster analysis of depressive symptoms

\section{DISCUSSION}

In our sample, the depression was identified in $26.7 \%$ of participating studentswho participated in the sample. This frequency is 2-3 times greater than that notedreported for in the general population (26). Studies in which the BDI was used to reportdetermine the prevalence of depression have reported a wide range of results (Table 3 ). In additionAdditionally, our findings waswere similar to the results of many studies in which the BDI or similar diagnostic in- 
struments were used $(5,9,10,13,27-31)$, including studies that have been carried out in the same region. A study of medical students in the Republic of Macedonia indicated that $10.4 \%$ of students had a BDI score greater than 17 (13). Twelve per cent of students in the present study had a BDI score greater than 16 . In a study conducted in adolescents in Croatia, 9.7\% of adolescents fulfilled the criteria for a moderate or severe depressive episode (32). In our sample, the prevalence was $9.1 \%$ of students.

\begin{tabular}{|l|l|l|}
\hline Study & Cut-off & Frequency \\
\hline Zoccolillo et al. (5) & $\mathrm{BDI}>9$ & $22 \%$ \\
\hline Mancevska et al. (13) & $\mathrm{BDI} \geq 17$ & $10.4 \%$ \\
\hline Tija et al. (9) & $\mathrm{BDI} \geq 8$ & $15.2 \%$ \\
\hline Clark et al. (10) & $\mathrm{BDI}>14$ & $25 \%$ \\
\hline Givens et al. (33) & $\mathrm{BDI}>8$ & $24 \%$ \\
\hline Hendryx et al (34) & $\mathrm{BDI}>9$ & $19 \%$ \\
\hline Leão PB (35) & $\mathrm{BDI} \geq 11$ & $20 \%$ \\
\hline
\end{tabular}

Table 4: Findings of several studies examining depression in medical students using the 21-item BDI

The mean BDI score in this sample of medical students was similar to that noted in studies ofon medical students in Macedonia (8.3 \pm 7.4$)$ (13) and heterogeneous student groups from Novi Sad, Serbia (32).

Regarding factor analysis of the scale, the scoring structure is variable among both different samples and similar samples. The affective, cognitive and somatic components are evident in various combinations in most studies (36). The cluster analysis in our study showed that every factor equallycontributed equally to the BDI score. A study that used the same cluster model in a population of medical student in Sao Paolo showed similar results. The authors collected BDI scores during the students' basic, intermediate and internship periods and found that the total BDI scores were highest during the internship period (11.7) and lowest during the intermediate period (7.0). The principal cluster responsible for the BDI score was the affective cluster (25). We analysed students in their fourth year, a year that represents the intermediate period of medical education. Analysing the characteristics of depressive symptoms among medical students is particularly relevant forto assisting medical professionals in addressing the different patterns of depression noted in this population and developing specific coping strategies.

No difference in the frequency or intensity of depression with regard to gender was established in this study sample. This finding is surprising in light of the fact that the frequency of depression in the general population is greater in women (37) and that similar results have beenthis gender difference has been reported in other studies involving medical students $(3,12,38)$. However, gender differences appear during adolescence (39), and at that time, the differences are not yetoccursfixed, as they are later in life (40). Thus, we could also interpret our findings in that manner. Another implication of our finding is that the causes of depression in medical students are of such a nature that both men and women are equally sensitive to them. ThishasSimilar results have already been reported for medical students in other studies (9).

The limitations of our study includeing the following: self-assessment scales were used for establishing the frequency of depression and suicidal risk, the investigated sample was relatively small, and the number of measured variables was also small. Future research in a similar population that includes a larger number of variables should be conducted to replicate our results, especiallyparticularly the absence of a significant difference in scores between genders.

\section{CONCLUSION}

With a $26.7 \%$ prevalence of depression, which is more than twice as high as that in the general population, medical student represent a population that is vulnerable to developing depressive mood disorders. The results of our study emphasise the need to develop programs to support and assist students in their health environment, with the objective identifying depression early to prevent future consequences.

\section{LITERATURE}

1. Mowbray CT, Megivern D, Mandiberg JM et al. Campus mental health services: Recommendations for change. Am J Orthopsychiat 2006; 76: 226-37.

2. Anonimno. American College Health Association National College Health Assessment Spring 2006 Reference Group data report (abridged). J Am Coll Health. 2007; 55: 195-206.

3. Mackenzie S, Wiegel JR, Mundt M, Brown D, Saewyc E. Depression and suicide ideation among students accessing campus health care. Am J Orthopsychiatry 2011; 81: 101-7.

4. Firth-Cozens J. Medical student stress. Med Educ 2001; 35: 6-7.

5. Zoccolillo M, Murphy GE, Wetzel RD. Depression among medical students. J Affect Disord 1986; 11: 91-6.

6. Assadi SM, Nakhaei MR, Najafi F, Fazel S. Mental health in three generations of Iranian medical students and doctors A cross-sectional study Soc Psychiatry Psychiatr Epidemiol 2007; 42: 57-60.

7. Seliger K, Brähler E. Mental health of students of medicinean empirical study. Psychotherapeut 2007; 52: 280-86.

8. Dahlin M, Joneborg N, Runeson B. Stress and depression among medical students: a cross-sectional study. Med Educ 2005; 39: 594-604.

9. Tjia J, Givens JL, Shea JA. Factors associated with undertreatment of medical student depression. J Am Coll Health 2005; 53: 219-24. 
10. Clark DC, Zeldow PB. Vicissitudes of depressed mood during four years of medical school. JAMA 1988; 260: 2521-8.

11. Tyssen R, Vaglum P, Grønvold NT, Ekeberg O. Suicidal ideation among medical students and young physicians: a nationwide and prospective study of prevalence and predictors. J Affect Disord 2001; 64: 69-79.

12. Schwenk TL, Davis L, Wimsatt LA. Depression, stigma, and suicidal ideation in medical students. JAMA 2010; 304: 1181-90.

13. Mancevska S, Bozinovska L, Tecce J, Pluncevik-Gligoroska J, Sivevska-Smilevska E. Depression, anxiety and substance use in medical students in the Republic of Macedonia. Bratisl Lek Listy 2008; 109: 568-726.

14. Klemenc-Ketis Z, Kersnik J, Eder K, Colaric D. Factors associated with health-related quality of life among university students. Srp Arh Celok Lek 2011; 139: 197-202.

15. Hysenbegasi A, Hass SL, Rowland CR. The impact of depression on the academic productivity of university students. J Ment Health Policy Eco 2005; 8: 145-51

16. Hem E, Haldorsen T, Aasland OG, Tyssen R, Vaglum P, Ekeberg O. Suicide rates according to education with a particular focus on physicians in Norway 1960-2000. Psychol Med 2005; 35: 873-80.

17. Eisenberg D, Golberstein E, Gollust SE. Help-seeking and access to mental health care in a university student population. Med Care 2007; 45: 594-601.

18. Hooper C, Meakin R, Jones M. Where students go when they are ill: how medical students access health care. Med Educ 2005; 39: 588-93.

19. Chew-Graham CA, Rogers A, Yassin N. 'I wouldn't want it on my CV or their records': medical students' experiences of help-seeking for mental health problems. Med Educ 2003; 37: 873-80.

20. Beck AT, Ward C, Mendelson M. Beck Depression Inventory (BDI). Arch Gen Psychiatry 1961; 4: 561-71.

21. Novović Z, Mihić L, Tovilović S, Jovanović V, Biro M. Psychometric characteristics of the Beck depression inventory on a Serbian student sample. Psihologija. 2011; 44(3):225-243.

22. Timotijević I, Paunović VR. Instrumenti kliničke procene u psihijatriji. Beograd, Institut za mentalno zdravlje; 2003.

23. Beck AT, Steer RA, Brown GK. Beck Depreession Inventory. 2nd editon manual. San Antonio: The Psychological Corporation; 1996.

24. Ward LC. Comparison of factor structure models for the Beck Depression Inventory-II. Psychol Assess 2006; 18: 81-8.

25. Baldassin S, Alves TC, de Andrade AG, Nogueira Martins LA. The characteristics of depressive symptoms in medical students during medical education and training: a cross-sectional study. BMC Med Educ. 2008 Dec 11;8:60.
26. Copeland JR, Beekman AT, Dewey ME, et al. Depression in Europe. Geographical distribution among older people. Br J Psychiatry 1999; 174: 312-21.

27. Kongsomboon K. Psychological problems and overweight in medical students compared to students from Faculty of Humanities, Srinakharinwirot University, Thailand. J Med Assoc Thai 2010; 93: S106-13.

28. Ball S, Bax A. Self-care in medical education: effectiveness of health-habits interventions for first-year medical students. Acad Med 2002; 77: 911-17.

29. Ahmadi J, Kamel M, Ahmed MG, Bayoumi FA, Moneenum AA. Dubai Medical Collegestudents' scores on the Beck Depression Inventory. IRCMJ 2008; 10: $169-72$.

30. Honney K, Buszewicz M, Coppola W, Griffin M. Comparison of levels of depression in medical and nonmedical students. Clin Teach 2010; 7: 180-4.

31. Lewinsohn PM, Hops H, Roberts RE, Seeley JR, Andrews JA. Adolescent psychopathology: I. Prevalence and incidence of depression and other DSM-III-R disorders in high school students. J Abnorm Psychol 1993; 102: 133-44.

32. Degmecić D, Filaković P. Depression and suicidality in the adolescents in Osijek, Croatia. Coll Antropol. 2008; 32: $143-5$.

33. Givens JL, Tjia J. Depressed medical students' use of mental health services and barriers to use. Acad Med. 2002; 77: 918-21.

34. Hendryx MS, Haviland MG, Shaw DG. Dimensions of alexithymia and their relationships to anxiety and depression. J Pers Assess. 1991 Apr;56(2):227-37.

35. Leão PB, Martins LA, Menezes PR, Bellodi PL. Wellbeing and help-seeking: an exploratory study among final-year medical students. Rev Assoc Med Bras 2011; 57: 379-86.

36. Vanheule S, Desmet M, Groenvynck H, Rosseel Y, Fontaine J. The factor structure of the Beck Depression Inventory-II: an evaluation. Assessment. 2008;15:177-87.

37. Blazer DG, Kessler RC, McGonagle KA, Swartz MS. The prevalence and distribution of major depression in a national community sample: the National Comorbidity Survey. Am J Psychiatry 1994; 151: 979-86.

38. Roh MS, Jeon HJ, Kim H, Han SK, Hahm BJ. The prevalence and impact of depression among medical students: a nationwide cross-sectional study in South Korea. Acad Med 2010; 85: 1384-90.

39. Ignjatović-Ristić D, Lazić LJ, Petrović D. Depressive disorder/symptoms in adolescence. World Journal of Biological Psychiatry 2001; 2 (suppl 1)

40. Hankin BL, Abramson LY, Moffitt TE, Silva PA, McGee $\mathrm{R}$, Angell KE. Development of depression from preadolescence to young adulthood: emerging gender differences in a 10-year longitudinal study. J Abnorm Psychol 1998; 107: 128-40. 